Western University

Scholarship@Western

Department of English Publications

English Department

Spring 2008

\title{
The Line, the Crack, and the Possibility of Architecture: Figure, Ground, Feminist Performance
}

Kim Solga
The University of Western Ontario

Follow this and additional works at: https://ir.lib.uwo.ca/englishpub

Part of the English Language and Literature Commons, and the Theatre and Performance Studies Commons

Citation of this paper:

Solga, Kim, "The Line, the Crack, and the Possibility of Architecture: Figure, Ground, Feminist Performance" (2008). Department of English Publications. 11.

https://ir.lib.uwo.ca/englishpub/11 


\section{KIM SolgA}

\section{The Line, the Crack, and the Possibility of Architecture: Figure, Ground, Feminist Performance ${ }^{1}$}

How and where do architecture and performance collide? Theatre studies has been, over the course of the last decade, increasingly interested in the relationship between stage and space; that interest, however, has primarily been figured by marrying theories of human geography with studies of theatrical performance. "The Line, the Crack, and the Possibility of Architecture" asks what it might mean to explore the spaces of performance through the lens of another plastic art - the art of building — and investigates what the discourses of architecture theory, both classical and (post)modern, might have to say to those of us who study the vicissitudes of feminist performance. The article tracks a figure I call the guerrilla actress-architect; she uses her performing body to reshape the plastic spaces of her world and asks us to consider the possibility that feminist performance may, in fact, be a kind of living architectural practice.

Où se croisent l'architecture et la performance? Au cours des dix dernières années, des chercheurs en études théâtrales s'intéressent de plus en plus au rapport entre la scène et l'espace. Or, cet intérêt s'est manifesté principalement par le recours à des théories de la géographie humaine dans le contexte d'études de la représentation théâtrale. Solga se demande ce qui se produit quand on regarde l'espace de la performance à travers la lentille d'un autre art plastique : l'art de la construction. Elle explore ensuite ce qu'aurait à dire la théorie de l'architecture, tant classique que (post)moderne, à ceux d'entre nous qui étudions les vicissitudes de la performance féministe. Solga suit enfin la piste de la comédienne-architecte guérilla, une figure qui sort de son corps de comédienne pour transformer les espaces plastiques de son monde et nous demande d'imaginer que la performance féministe peut en fait constituer un type de pratique architecturale vivante.

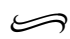

$[\mathrm{E}]$ one of the reasons for this is to prevent any creature from gaining access and making nests there or accumulating filth and seeds, which might result in the wild-fig 
sprouting from within the wall. I have seen an incredible weight, a whole mass of stone, disturbed by a single root.

(Leon Battista Alberti, On the Art of Building 73)

Dorothy falls and Alice falls, but into other worlds of magic and strangeness. Adam, Lucifer, Humpty Dumpty, and Icarus fall to less desirable ends. These figures of the construction called masculinity attempt to rise to power and fail, lose, fall from grace. The feminine ones drop out, fall down the hatch, use the exits [...]. The position to take is perched on the rim of the hole, at the moment the trap door closes, ready to fall. Not to fall from, but into.

(Jennifer Bloomer, Architecture and the Text 162)

Air, that which brings us together and separates us. Which unites us and leaves a space for us between us.

(Luce Irigaray, i love to you 148)

\section{Ground plans}

Picture a root cellar door, London, 1665. Locked inside: the maid of a wealthy family, dying of plague, confined by her master to fortify against the illness creeping in through his walls. Trapped outside: her daughter, Morse, hinged between loss, rage, and mourning. Mother asks daughter to hold her. Morse cannot: the door is fast, cuts between them. Still they fight, struggle for connection, lie with their mouths pressed up against the crack between door and casement. They inhale one another's breath (Wallace 58).

The door is architecture erected by capital to insist upon the relative worth of the sick and the well, the wealthy and their chattel; the crack is the echo of their separation. But the crack is also the possibility of coming together, a last chance for contact as one body unravels beyond the touch of the other. The mother does indeed die before long. Soon the master's other servants die, then the master and his wife die, and finally his own daughter, Lissa, dies. But Morse survives, by chance or luck, perhaps by cunning, perhaps by magic $(64)^{2}$; she steals the dress and the surname of the rich man's little girl, then steals from the house, steals into the night, steals in through the single open window of another plague house, boarded up somewhere else in the city. She carries the freight of the locked door on her back. She carries the hope in its crack.

This is a story of lines and cracks: of the supposedly unbreachable skins of built spaces and the extraordinary power 
performance holds to break into them, to excavate the bodily relations they construct and reproduce, and to play those relations in a different key. I begin from two interwoven premises. First: that architecture, as both the theory and practice of built space, is always both literal and metaphoric: it is literal space shaped by metaphor, specifically by metaphors of containment and separation. Built space is erected between things; it has an unmistakable, originary dividing function. I cannot help but notice, as I wander around my home city, that contemporary architects seek more and more to challenge that dividing function: I think of recent work by KPMB on the Gardiner Museum of Ceramic Art and by Jack Diamond on the Four Seasons Centre for the Performing Arts, both in Toronto; both projects take shape around large walls of glass arranged to link those within to those on the street. And yet in so doing they inevitably reiterate division as the central operation through which all architectural processes are understood. To put up a wall is to put something between us; if the wall is glass, the "something between us" is all the more longing and desire. That is architecture's pleasure as well as its burden.

My second premise may perhaps now seem obvious: architecture is always already about bodies. Not body, but bodies: not a body in isolation, but bodies in messy, intimate, historical relation with one another. ${ }^{3}$ Architecture's classical origin story begins with Vitruvian Man, conceived in Augustan Rome by Marcus Vitruvius Pollio and later sketched by Leonardo da Vinci in Renaissance Milan. ${ }^{4} \mathrm{~A}$ body with two fathers and no mother, Vitruvian Man is the "ideal" body (which may be that of Apollo or, as Indra McEwen has argued provocatively, of Augustus himself and, by association, the imperial Roman project [198]) on whose proportions Vitruvius bases a set of measurements for classical architecture practice. That this body is male there can be no doubt: from Vitruvius's laundry list of its proportional features we can glean, among other things, that Vitruvian Man is six feet tall, long armed and barrel-chested (Ten Books 72). And yet something-a little detail Vitruvius offers in his extended description-disturbs, troubles the sanctity of this body's abstracted, purified, singular maleness:

[I]n the human body the central point is naturally the navel. For if a man be placed flat on his back, with his hands and feet extended, and a pair of compasses centred at his navel, the fingers and toes of his two hands and feet will touch the circumference of a circle 
described therefrom. And just as the human body yields a circular outline, so too a square figure may be found from it. (73)

Classical architecture's symmetrical perfection, its ideal geometry, is born from the navel of this oddly two-dimensional, utterly motherless figure, splayed flat on his back with arms and legs outstretched. And yet the sexual implications of this root, its material ground, disappear as soon as they arise. The navel is the locus of a primal connection between mother and child; Vitruvian man is a body that, curiously, must have been born in order to assume his rarefied place in theory, as architecture's founding metaphor, but he buries beneath his magical, mathematical perfection the material, lived, sexed human body in intimate relation to another material, lived, sexed human body that is the true basis of architecture's preferred geometry. In the process, he at once raises and dismisses the spectre of his missing mother and of the sexual, gendered labour of her contribution to his place at the pinnacle of architecture theory. Vitruvian theory thus encodes, at its very core (heart, navel), specific assumptions about what kinds of bodies count in this matter of built space, what kinds of relations between bodies are permissible within the strong and perfectly proportioned walls of classical theory and practice-and what kinds of relations are forbidden. ${ }^{5}$

Together, these two premises-that architecture is mobilized by metaphors of containment and separation, and that these metaphors are themselves grounded in architecture theory's sly translation of material (female, sexual) bodies in labour into an idealized (male) body as figure - combine to drive the assumption that guides the rest of this paper: that architecture and performance have a great deal more to do with one another than either architecture or performance theorists have previously assumed. I want to be clear that I do not understand the relationship between performance and architecture to be a literal one: I am not interested in the material shape of performance spaces, nor am I interested in the "architecture" of specific scenographic designs except as such design might impact larger theoretical questions about the concatenation of bodies in performance space. This is not an article about performance architecture in any typical sense of the term. Instead, I am interested in architecture's guiding metaphors, their implications for lived embodiment beyond metaphor, and the role performance can play in bringing those metaphors, and those implications, more clearly into view. 
At its own root, "performance" points to the labouring body: Shannon Jackson notes that it derives from a word meaning "to furnish forth, 'to carry forward,' to bring into being"' (13). More significantly, while architecture theory disavows complex, heterogeneous embodiment as a condition of its classical origin story, performance, as both a long-standing artistic practice and a twentieth-century theoretical one, is defined by its often-vexed debates over the manifold, "messy" nature of theatrical embodiment. The question of bodies, plural, lies at the heart of performance theory and practice; performance thus holds the power to break the skin of architecture's figural fantasy and to excavate the bodies that lie buried beneath.

I offer this paper as a first step toward what I am calling an architecture of feminist performance precisely because the bodies that architecture theory buries are not neutral: they are female bodies, the absent mother of Vitruvian man and the women whose own plastic production (as weavers of tapestries and traditional builders of space) is obscured in the drive to transform practice into theory, space into metaphor, the material into the ideal, architecture into a form of philosophy (see Bergren, "Architecture" 23-31 and "Female Fetish" 81-84). To excavate architecture's theoretical walls is to shift its gender (im)balance, to pry open ideal figures in order to encounter the lived, sexed bodies that labour, together, at the discipline's core. Feminist performance-as a theory and practice grounded not simply in an unproblematic return of the "lived" female body to the space of the stage, but rather in the interrogation and complication of all bodily representation-offers one rich site at which such an encounter might be arranged. Intimately engaged with the question of bodies, and the sexual, social, political and racial questions that govern their material interaction in the space of representation, feminist performance can operate as a lens through which we may understand how architecture shapes its corporeal objects and how they might be reshaped through the interactive work of bodies in performance.

\section{Seeing through walls}

Jennifer Bloomer tells us that "the crack is the possibility of architecture" ("Nature Morte" 244): this is a renegade assertion. Classical building practice-the kind of architecture handed down from Vitruvius, enforced by Alberti during the Italian Renaissance, and practiced, with variations, even today-is marked by the straight, measured line and its material echo, the smooth, white, impermeable wall. Wall and line sign the clean, the 
proper, the well ordered: Vitruvius and Alberti are to architecture theory and practice what Plato and Aristotle are to theatre and performance theory. No surprise, then, that the classical wall (Alberti's wall, architecture's seminal wall) has become ground zero of feminist critiques by writers such as Bloomer and Catherine Ingraham. ${ }^{6}$ Smooth, seamless, cleansed of distracting defect, the wall is a screen erected to project the moral interior of a space, to offer watchful eyes the illusion of transparent hearts. Mark Wigley reminds me that the classical wall is governed by the Renaissance fantasy of specular authority: its corporeal correlative is the eye, that small corner of the body that can be most effectively used to project oneself beyond the perceived limits of the body and into perspectival space. Arranged around the presumed power of the eye to own and control space, the classical wall is a stern sentinel, brooking no bodily pleasure as it stratifies and purifies human relations:

[T] he wall is not simply looked at, inspected by a detached eye. Its white surface actively assists the eye by erasing its own materiality, its texture, its color, its sensuality, as necessarily distracting forms of dirt. [...] Neither material nor immaterial, it is meant to be seen through. By effacing itself before the eye it makes possible, it produces the effect of an eye detached from what it sees. (Wigley 360 , my emphasis)

Wall separates eye from body, body from materiality, just as it separates master from servant, husband from wife, bodies from themselves and from each other, from spontaneous pleasure, from inappropriate fecundity (347). The wall keeps you clean, keeps you in line, keeps you outside yourself by holding you inside the lines. Or, at least, it tries.

Bloomer's crack - the possibility of a less stark and sanitized built frame; the possibility of deconstructing the very idea of the frame-breaks defiant within classical logic. The crack is the sign of the wall's hegemony, but also the proof that its power is no more than fantasy, than illusion. The crack is where the wild figs grow, those pernicious fruits that Alberti fears will rip apart his carefully placed foundation stones (see my epigraph above). The crack is home to all the bodies and bodily relations line and wall cannot comprehend, cannot order, cannot see through; they cram in, fracture the base, threaten ruins. The crack is a true abject assemblage ${ }^{7}$ : it frames, at last, a place within architecture for desire not governed 
by the cruel disappointments of specularity, the inevitable failure of the gaze-bound subject to achieve its untouchable Other. ${ }^{8}$ The crack makes place for the body that experiences and practices its own desiring (Bloomer, "A lay" 52); it is the ghost in the walls, the space of unexpected air between two quarantined bodies. It is a staging ground for a more equitable, more ethical kind of living room.

The crack is both metaphor and materiality, both theory and practice, and like its arch-nemesis it has a textual echo: as wall is to line, the crack is to what Bloomer calls the poché-the space between walls that, on blueprints, is blacked out, blended into the background (Architecture 177-78). What worlds, Bloomer charges us, might we find in the black of the blueprint? What if, bound up too tightly by the pressures of Humpty Dumpty (the pressure to fit, perfectly, together again), we choose to play Alice or Dorothy, to embrace the fall into this forgotten space instead? Within the ubiquitous wall from the top of which Humpty suffers his fall, the rejects of classical architecture wage a guerrilla war against the fussy King's horses and men. Their architecture is an assemblage of bodies and matter in messy, sometimes euphoric and sometimes debilitating contact with one another. This isn't architecture as solid, intractable matter; this is matter as plastic performance.

In a charming and provocative article in a recent issue of Theatre Journal, Aleksandra Wolska asks whether performance theory's fetish for theatre's supposedly inherent ephemerality truly does justice to the work of its making (86). Her conclusion is no: what the arguments of Derrida, Blau, Phelan, and others who have made exciting yet flawed cases for performance's unmarked-ness fail to take into account is the inevitable plasticity of performance, the ways in which theatre's "things-actors' bodies, objects, and elements of design"-always defy the linearity of the story (the show begins; it ends; it disappears into memory, into air) on which the ephemerality claim is based (88). Scene and costume shops and rehearsal spaces are often relegated to the poché of performance theory and criticism, ironic given that they tell a decidedly non-Euclidean (non-rectilinear) story of performative production. In these spaces ideas are tried out, discarded, tried again, returned to later or not at all, or perhaps reinvented in another show down the road. In the worlds before and beyond the curtain, "performance comes into being [...] in the often absurd struggle with the resistance of matter" (93), as a function not of pure performance magic, but of the mundane yet essential techne that informs its plastic creation and allows its very materiality to be 
re-tooled and redeployed in a rich, multi-vectored afterlife.

Wolska reminds me that performance is really a plastic art, an art of building (props, scenery, costumes, characters, montages) infused at every level with technology (tools, computer-aided design, bodies themselves). The cracks in mimesis are filled with the everyday labour that holds the line between our world and the "magic" world of performance. Bloomer's poché, Alberti's crack, and the alternative practices they promise to stage, meanwhile, remind me that architecture (perhaps the most plastic of arts), even as it fears and disavows its buried bodies, carries along with them a secret impulse to perform. The crack marks the spot where performance and architecture collide with one another, where plastic production comes alive as theatre, because the crack is architecture ruptured by the power of the mobile, expansive, and manipulable organic body.

In case this is starting to sound a bit far-fetched, it's worth remembering that Elin Diamond implies this very argument as she develops her now-canonical theory of gestic feminist performance. ${ }^{9}$ The walls of classical realism (the fourth wall; the carefully crafted walls of naturalism's living room set; the seamless skin of realism's acting body) serve the domineering ideologies of a modern middle-class bent on containing troubled and troublemaking women. Diamond's feminist gestus is the crack that splits those ideologies into their component arguments, allowing the violence they visit upon the bodies beneath them to push up into our consciousness while the missing bodies themselves emerge in a perspective-defying Brechtian double-optic. The feminist gestus carries the hope of generating, in place of the stultifying architectonic of conventional realism, a space between actor, character and spectator through which to release each not only into their material, historical relations with one another (as Brecht famously, if somewhat dryly, argued), but also into the pleasure those relations can and should bring, into a shared (though never identical) embodiment. Just as Bloomer would sprout Alberti's wild fig, would release the fecundity in the walls and find in them the pleasures of intercorporeality, Diamond pries open the space between acting body, acted body, and spectating body precisely in order to find the bodies - carnal, dynamic, desiring - bricked up between them. ${ }^{10}$ Diamond's feminist performer, working within the selfconscious Brechtian tradition, is, like Jennifer Bloomer, a guerrilla architect: she plays at the cracks, breaks them open, winks at the fall into, and surfaces to present us with the bodies, with the bodily practices, that realism's stage "magic" walls off. 
My collision of Bloomer, Wolska, and Diamond at the point of the crack is meant to offer one view of the radical interdisciplinary potential of feminist architecture and performance theories. Wolska returns performance's labouring bodies, and the meandering, imperfect trajectory of their plastic practices, emphatically to view. Diamond's theory of the feminist gestus works as an architectural critique of realism's bodily practices: the singular body of the realist actor buries at least two bodies beneath it, and the feminist gestus is a performative excavation of those bodies. Meanwhile architecture theory, in the moment it falls into the wall, down Bloomer's rabbit hole, becomes performance. It becomes the messy work of improvisation (the wild fig will grow anywhere, any which way), a product of real labour rather than the sweet dream of clean and smooth surfaces. It becomes a matter of experimentation and play rather than a carefully framed stasis, a waiting for inevitable death. ${ }^{11}$ The wild fig is the sign of a guerrilla garden, a rebel habitation: hybrid identities thrive within such a space, mark accidents of shared dwelling - two conditions of performance's own hybrid, somewhat renegade process of coming-into-being. I'm well aware that I am playing, too, in the walls as I craft this argument, but I believe its benefits to each discipline are real. Feminist performance theory and practice offer architecture a provocative lens through which to comprehend the most radical implications of its forgotten debt to bodies and their material (gendered, raced, sexual) relations, ${ }^{12}$ while architecture theory, especially the work of feminist thinkers such as Bloomer, Wigley, Bergren, and Ingraham, offers feminist performance the means to think more fully through the space-making capacity of its own theoretical and practical activities.

I am arguing that architecture intersects with feminist performance at two key moments: the moment when we recognize the body as labouring, sensual, mobile; and the moment when we recognize the body as intercorporeal, as a body understood in its material and often sexual relations to other bodies. These are the two moments classical architecture theory denies as it divides bodies from one another and compartmentalizes them in space; these are also the two moments that feminist performance seeks to comprehend, interrogate, and problematize as it investigates the female body in the charged literal/metaphorical space of representation. In order to dig a bit deeper at this disciplinary intersection, the rest of this paper explores the performative building practices of a figure I call the "guerrilla actress/architect" in three different theatrical texts: Thomson Highway's Dry Lips Oughta Move to 
Kapuskasing (1989), Thomas Middleton and William Rowley's The Changeling (1623), and Naomi Wallace's One Flea Spare (1995). The guerrilla actress/architect is an upstart wild fig; she emerges from the crack where Diamond, Wolska, and Bloomer meet. She has a keen sense of how built space works on the bodies in her world and a flair for the feminist gestus. She takes upon herself the trappings of theatricality, plays a role (or several), and, through her self-conscious performance practices, reconfigures relations between her own and others' bodies and shifts the metaphorical contours of the space designed to hold them. The guerrilla actress/architect disrupts the stifling structures that support our containment and separation from our others with a performance that privileges instead an architecture of intercorporeality, an assemblage made from the space between bodies that honours the differences moving in the air between them.

One final coda: in the analyses that follow, I am interested in my subjects at the level of textual, not literal, performance. In other words, I am reading play scripts, not actual productions of those scripts. I have made this choice for two reasons. First, while the analysis of specific performance events is crucial to theatre studies, performance studies, and performance theory alike, I believe that performance criticism can also have real, practical value at the level of text. Every text for performance implies a theory of performance, an understanding of itself as performative that manifests both at the level of metaphor (the text's internal theatricality) and at the level of production (implied in stage directions and other practical details). To see a performance is to see one of many versions of a text; to read the text is to capture, even if only briefly, the possibility of several, often contradictory, performance opportunities colliding one with another. If we accept a play text as the ubiquitous "blueprint for performance," then we need to accept the reading, analysis, and theorization of that text as another, valuable form of its performance. ${ }^{13}$ Second, because I have chosen to focus on female characters who operate as builder-performers within the internal worlds of their plays, my analysis of their mimesis is not conditional upon the actual production of their texts. If anything, by reading their work at the level of text, I am better able to imagine the potential their performances hold for reshaping both the metaphysical contours of their plays' worlds and the literal space of those worlds' imagined stages.

\section{Radical Bodies, Origin Stories}

I first began thinking about the potential synergies between archi- 
tecture and performance several years ago while working on a paper about the performance of gender in Tomson Highway's Dry Lips Oughta Move To Kapuskasing. The centre of any such paper is necessarily Nanabush, the mythical Ojibway trickster figure who inhabits both male and female sexual positions fluidly, and who in Dry Lips is nominally gendered feminine but in fact always and only appears, via a series of outsized prosthetic female body parts, as gender performance incarnate. In Dry Lips, Nanabush embodies the "spirit" of three women alternately feared, loathed, and desired by the men of Wasaychigan Hill who are the main characters in the play: big-boobed Gazelle Nataways, big-bummed Patsy Pegahmagahbow, and big-bellied Black Lady Halked. As a trickster spirit with a wandering eye, Nanabush possesses the uncanny power of the double. She plays at least two parts at once, and she can appear in two places at once: in "real" space and time-the world of labour, of materiality, of complex intercorporeal relations - and in the world of magic, fantasy, and metaphor.

As I explored the play alongside plans for the original set design for its 1989 Theatre Passe Muraille premiere, the centre of my paper gradually shifted away from Nanabush's drag performances of feminine fantasy and onto the space in which she accomplishes these performances. ${ }^{14}$ Nanabush's "perch" (Highway 10), located on the upper level of the split stage designed by Brian Perchaluk for both the original and the revival performances of the play, operates as the realm of magic and invention, of what Aleksandra Wolska would call the techne of performance. The perch is Nanabush's dressing room and scene shop; here she builds her characters, tracing the reserve men's lewd imaginings by transforming her sets and switching her props and identities to both accord with and distort the images projected by their fantasies. When Nanabush is acting (and she is always acting), we know it: from the tricks she plays at Zachary's expense in the first scene (1516) to her climactic, parodic, teasing transformation into the dancing girl the men hungrily remember from a particularly difficult night at the Dickie Bird Tavern (85-87), the work of her performance work is always transparent. There is an invisible if unmistakable line between her plastic, self-conscious performance space and the "real" world of the reserve represented on the stage below, and Nanabush's only job is to breach it, repeatedly-to challenge the very logic of that line and its consequences for real bodies in real space and time.

Nanabush is a mythical figure in Ojibway culture, an origin figure. In Highway's hands, as a gender performer with designs on 
world making, Nanabush also has ties to another mythical origin figure: the chora of pre-Platonic philosophy, architecture's lost feminist ancestor. Plato deploys the chora as a feminized vessel with no abiding characteristics of its own; its role is to produce offspring as "a perfect replica of the paternal Form," generating the fiction of unmediated lineage from father to son on which theoretical architecture is then based (Bergren, "Architecture" 23). But the chora is not owned by Plato; Ann Bergren points out that "[b]ack before the making of a cosmos out of the disordered universe, the chora used to shake, in the manner of a winnowing basket, displacing the precursors of the four elements each to a different region of herself" (23, my emphasis). As she shakes the world into being, separating the harvest and releasing its residue to the wind (freeing it into other possible futures, other possible material relations), the chora establishes its relation not only to women's labour but also to the dance-like physicality, the performative pleasure such labour can entail. The chora as winnowing basket is the model of an embodied, movement-based architecture, architecture derived from and intimately indebted to the relationship between body and craft, body and the materials of its sustenance, body and the other bodies working alongside it. Bergren argues that the first architect is a woman and, moreover, that she is an architect because she loves to perform.

Nanabush is exactly such a mover and a shaker: she is the dancer (the dancing girl!)-as-labourer-as-architect, the propmaster, the scene-shaper, the scenester. She relishes putting on her kit, getting ready for the show in plain view of her audience (15-16, $85,95,117)$, and she uses her considerable performance wiles to "displace" the reserve's men: they end up in outlandish positions, awkward situations, and unexpected places (Zachary naked on Big Joey's couch [15-18]; all the men half-naked on the floor of the Dickie Bird tavern [87]). She puts the plastic (literally) back into her performances, revealing the fantastic that abides within the real, and the material within the magical. Nanabush isn't radical because she can remake her body over and over again in and through performance (although that's radical enough), but because she uses the obviously pleasurable labour of her performances to transform the play's divisional structures, the gap between fantasy and experience that characterizes the gendered, as well as the cultural and mythical, ontologies of the reserve. She makes a mockery of the stage's separatist spaces with a body that is at once miraculous and intensely physical, at once a builder and a performer.

Gazelle Nataways, one of Nanabush's performative incarna- 
tions, plays hockey with the Wasy Wailerettes, the reserve's allfemale semi-pro team; she gets hit with a slap shot (fired by none other than her metatheatrical alter-ego, Black Lady Halked), and the puck "magically" disappears down the substantial "crack" (81) between her (prosthetic) breasts. Alberti-like, the reserve's men fear the crack-"They say that puck slid somewhere deep, deep into the folds of her fleshy, womanly juices" says Pierre (81) — but, as we might expect from such a plump description, the crack is less a black hole than a guerrilla garden. Ripe to the point of being a true menace to classical decorum, Nanabush/Gazelle's prosthetic bosom crack incubates and nurtures that missing "particular" puck, and with it the memories (painful pasts, violent histories, lost myths) the men in this play would prefer to bury, forget, drink away, or otherwise, Puck-like, misplace. From this guerrilla garden (which is both prosthetic, performative, and yet also the sign of a real female body on stage), Nanabush stages a breach in the lines between violence and desire, past and present, body and fantasylines of containment and separation to which the men cling. The story of the disappearance of the "particular" puck takes the men back in time to that night at the Dickie Bird tavern when Gazelle was the dancing girl and Black Lady was about to give birth, drunk, tweaked out, leaning against a jukebox without the aid of Big Joey, her baby's father. Nanabush/Gazelle is right there with them, dressed to the nines and prepared to do the scene all over again. She begins her revival performance up on her perch, but quickly moves it into the realm of the "real" as she appears on a table on the lower stage before the hooting, appreciative men. Shifting shape as she breaks through the invisible wall that separates her space from their space, performance from reality, and past from present, she replays the infamous night of the original strip-tease in a thoroughly self-conscious key. The men, excited to the point of their own ripe fecundity by the incarnate memory of Gazelle stripping on the table, find themselves with their pants around their ankles as the lights come back up again (87), the lines dividing actual flesh from pleasurable fantasy much more blurry than before. Shortly after this episode, Dickie Bird Halked rapes Nanabush (in the spirit of Patsy), completing the journey from pleasurable fantasy to brutal violence.

As Dickie Bird attacks, Nanabush moves back up to her perch to confront her audience with the material residue of rape: her bloodied, bleeding lower body. Her transition back across the lines between our world, the men's world, and her own argues forcefully that such lines are not simply a fantasy of tidy bodily containment 
and separation, but a violent fantasy that promotes ownership and control of one body over another rather than mutual, pleasurable interaction between them. Nanabush's theatrics produce a palpable architectural critique here, one that resonates both within and beyond the play's stage design. The logic of a stage divided from itself not only does not hold, but is not safe, especially for women. Nanabush repeatedly crosses the line separating her perch from the men's more literal world and uses her dynamic, heterogeneous, multi-identified performance body to challenge the men's belief in the fantasy of the line as such, as well as in the specific lines that supposedly mark past as separate from present, myth from reality, men from women, and fantasy itself as harmless, as separate from violence against real female bodies. Dressed voluptuously as Gazelle, innocently as Patsy, or threateningly as Black Lady, Nanabush dive-bombs the men over and again and catches them with their pants down. She reminds them of how their enslavement to fantasies of anxiety and desire produces lines of containment and separation that bracket off the real bodies, needs, and desires of the reserve's men and women, and she offers brutal representations of the material consequences for female bodies of the men's separatist imaginings. Her seductive bosom crack holds the reserve's troubled sexual history, and, as Nanabush/Gazelle shakes her groove thing, the cruellest episodes of that history fall out, threatening (perhaps promising) to reshape Wasaychigan Hill's embodied landscape with the stories they expose.

\section{Rebel Habitations}

Highway's Nanabush has an ancestor in an unlikely place: Thomas Middleton and William Rowley's gruesome Jacobean revenge tragedy, The Changeling. Beatrice Joanna has ordered the murder of the man betrothed to her against her will and has been raped by and blackmailed into a sexual liaison with her hired killer, de Flores. It is now the top of Act 4, and she stands alone on stage before her audience wondering aloud how, thus sullied, she may ever approach her marriage bed and her chosen partner, Alsemero. Ever the pragmatist, Beatrice Joanna's primary concern is not for the shame her sexual impurity may bring her new husband, but for the danger in which that shame may place her once it becomes known. Alsemero, she tells us, is a clever man, "clear in understanding" (4.1.6), before whom her transgression will without question shine out of her body, condemning her to his rough justice. But Alsemero is not just clever, she goes on to reason: he is also "a cunning gamester" (4.1.17), and to outwit him at his own game she 
will need the tools of his own trade. No sooner has she made this observation than she comes upon his "closet," a private chamber (in performance, possibly the theatre's tiring house) tricked out with an alchemist's collection of vials and potions designed to help a hapless husband discover all of his wife's dirty secrets.

Alsemero's closet-in which Beatrice Joanna finds glasses marked "C", designed to let a suspicious father or husband "know whether a woman be with child or no" (4.1.26), and "M," designed to expose a sullied maid - is a version of the secret interior space at the heart of every seventeenth-century English home in which the (male) head of house kept his private papers, journals of accounts and observations, all manner of personal stuff. A closet could be as large as a study or as small as a locked box or cabinet, depending upon the wealth and status of its owner, but the possibilities it held expanded quite beyond these objective physical limits. The closet was a place of self-fashioning for the household head, a place of gestation for his nascent sense of interiority, the locus of his becoming as a truly modern subject. ${ }^{15}$ It was also, however, a place whose interiorizing function depended directly upon a concomitant externalization: of the habits, moods, and secret pleasures of the wife, she whose control over the household, as Mark Wigley observes, operated interstitially. It reached from the front door, beyond which the wife was not able to venture without proper sanction, to the door of her master's locked study, into which she could not enter without permission (348). For the four walls of the study or strong-box to do their proper work for him, to produce the contours of his private self in a space sequestered beyond the material and the sexual (347), they first needed to be able to know her, to tame the threats posed by her amorphous, slippery body. Closets like Alsemero's were nothing less than knowledge-producing machines, dependent for their inward gaze upon their ability to classify, exteriorize, and then expel the lived complexities, the folds and pleasures, of those bodies that threatened, in their own intimate inwardness and its troubling invisibility, to disprove their master's exclusive claims to an enlightened interior life.

The early modern closet performs classical architecture's founding fantasy of disembodiment: it is a structure designed to harness a wife's or daughter's bodily complexities and render her inanimate, de-materialized, to produce her as a contained, obedient, proper body that is also a "patriarchal territory" (Stallybrass), a literal piece of property (Ingraham 54). The closet generates and fortifies its walls by bricking up within them the fecund, the sexual, the reproductive, the lived body of the supposedly unruly early 
modern female; her generative powers become its generative powers, and by the magic of intellectual transference the early modern husband-who claims both closet walls and the body within them as his property-becomes in turn both parent and child to his own emerging subjectivity. The closet becomes the site of male reproductive fantasy, the Vitruvian fantasy of self-generation; absorbed into the closet walls, made part of the exterior space that divines the interior (male) self, the woman's body, stripped of both its sentient complexities and its more prosaic corporeality, becomes guarantor of the domestic fortress, its strength and its propriety. Bricked in, she stabilizes the house that evacuates her.

Beatrice Joanna will have none of this. Astute enough to cast her relationship to Alsemero as a battle of wits in the name of sheer survival, she sets about to learn the codes of knowledge Alsemero's potion closet lays out and to reproduce them on (rather than in) her body as faithfully as she can. She tricks her maid, Diaphanta, into drinking the contents of glass " $M$," protesting that she disbelieves Diaphanta's claims to virginity. Playing for a moment the household head, she administers the liquid and watches Diaphanta gape, sneeze and laugh as the potion book claims a woman who is still a "maid" should do. Later, when Alsemero offers the glass to Beatrice Joanna, she need do no more than perform the effects she has already witnessed, "feign[ing] 'em handsomely" (4.2.139).

Replacing the signs of sure knowledge with the effects of a "cunning" (4.2.138) performance (replacing the commodifiable female body, meant to reproduce within itself the body of the heir, with a performing body that generates on its surface the effect of myriad other bodies, none of them necessarily patrilineal), Beatrice Joanna cracks open the closet walls that would contain her, jamming a wedge between her body and Alsemero's episteme. Her play erupts in the space between his expectation and its seamless reproduction inside her belly and brain, exchanging a dynamic, doubled subjectivity for the closet's impulse to render her body static and localizable. But Beatrice Joanna's dynamism is not just that of a slippery and sexually active body; hers is the dynamism of such a body in performance, as performance, its thrilling and dangerous ability to transform itself and its surroundings with a well-timed sneeze or cough, to shift what always appears in a moment to be a localized and controllable materiality across worlds and into different dimensions. For Alsemero, the closet and its contents, like the body of his wife, is an open book, self-evident architecture. Beatrice Joanna's play has an alchemical effect on this ludic space: as she mimics its impulse to 
knowledge, the closet loses its assumed transparency, grows opaque, molts from enclosure into horizon. Secretly altered (Alsemero remains sure he has known his wife through the potion's apparently accurate effects), the closet becomes "an event of whiteness" (Bachelard 81): a blank slate, a space of transformation, a stage upon which to perform a protection spell, to stage an unexpected self.

Beatrice Joanna is an actress, but she is also an architect. In fact, she is an architect precisely because she is an actress: her performance accomplishes a reconfiguration of her body's knowable limits which, in turn, alters the metaphysical frame of the space designed to contain that body by assuming it can be known without limit, can be easily called forth and just as easily locked up tight. Beatrice Joanna alters the structural ground-rules of her world as she uses the occasion of her potential confinement to transform the closet from a symbol of classical architecture into a stage space. Insinuating her radicalized, secretly performing body ("radicalized" because, as a performing body, it always implies the possibility of infinite other bodies) into the space of its supposed enclosure, Beatrice Joanna remakes herself while exposing the closet's structural logic, its undisclosed dependence upon a seamless, mimetic correlation between knowledge and embodiment, between the visible and the seen/owned. The fantasy of the closet's smooth, impermeable, enclosing walls and their ability to reflect an interiorized (male) subject depends directly upon the fantasy of an impermeable mimesis, a willing disappearance effected by the female body that acts as guarantor of both walls and the subjectivity they envelop/articulate. But when Beatrice Joanna's dissident mimesis breaks into the closet's private spaces, it finds not an enclosure but a theatre. ${ }^{16}$ The bodies in its walls, the bodies propping up its subjectivating project are not just female bodies, but performing bodies, bodies whose true threat is their ability to embody more than one self in more than one dimension, to overturn the accepted hierarchy between architecture and embodiment implied by the logic of the closet. Beatrice Joanna's "guerrilla" practice bleeds the closet's enclosing, purifying function into its secret materiality, a materiality produced by and guaranteed only in performance.

\section{Reclaimed Ground}

Beatrice Joanna's claims on her husband's closet are finally ambiguous; the gains she makes in Act 4 are lost in Act 5 when she 
finds herself bound and punished for her actions within that very closet, emerging penitent to end the play. But these losses are relative; once tampered with, Alsemero's closet is never quite the same, and, even as he locks his wayward wife in it, she becomes his spook, haunting his own claim in the final act to a reversal of fortune. Is she truly penitent, or just faking it once more? Alsemero will never know; he will have to live with the ghost in his walls. ${ }^{17}$

Naomi Wallace's One Flea Spare is similarly crammed with ghosts, spooks in the walls; they are the dead of a London plague year. Morse is, finally, the play's only survivor: Wallace's metaframe finds Morse in prison, defiant, under interrogation in the matter of the deaths of the other characters. If this is a ghost story, it's hers (Baley 243). But Morse is not haunted by her dead: what she has lost, what she mourns, what she craves is the connective tissue between other people's bodies and her own, the touch denied her at the door to her mother's tomb. The broad social spaces of her world are filled with a desperate fear of contamination by disease, especially disease carried by those of lesser privilege. Architecture guarantees these fears; the walls of this world are high and strong, and the doors are locked. And these walls plague Morse: they are her spook, her target, her enemy. But they are also her putty, her clay, her stage: she will lay her hands on them, force her body through them, make them give way to their cracks. She will transform the (seemingly) impermeable skin of a house shut up tight against other people's plague into the porous skin of other people's bodies and open them like flowers to one another. Architecture is Morse's ghost, and she, both low-class body and seasoned guerrilla performer, is architecture's pestilence, its terror.

Snelgrave and his wife Darcy have lived nearly a month locked up in their own house under a plague quarantine when Morse and Bunce, a sailor on the run from the Navy's press gangs, find their way inside. The house is almost completely boarded up in an effort to keep any traces of disease confined, but Morse finds the crack and falls in. While Bunce enters through the cellar, Morse comes over the rooftops and through the single open window (8). Now, all four are trapped inside the Snelgrave walls. The Snelgraves are "terrified of contact" with Bunce (9); they fear he is ill, but they also fear he is not "one of" them (13). Morse saves herself this shunning by pretending to be Lissa Braithwaite, who was of the Snelgraves' status. The threat of plague becomes shorthand for class panic, and the house the frame of the Snelgraves' war against their others.

Wallace arranges the play around the expectation of 
house/wall/door as barrier, but only to exploit that expectation in order to make connections between what I earlier called architecture's "supposedly unbreachable skin" and our much more porous own. Skins multiply in this play, much as do body parts in Dry Lips and bodily effects in The Changeling, making both symbolic and plastic connections between the guerrilla performer's malleable body and its effects on the (real, historical) bodies and spaces around it. The interior skin of the Snelgrave house, drenched daily in vinegar to kill the invisible plague spores it may harbour, is the skin of the body uncertain about its own infection, fighting to keep a physical distance from other bodies for the sake of sheer survival. The vinegar solution that seals the walls from germs also keeps bodies in line and class barriers in place, for a time: Bunce, not "one of" them, is made to spread the vinegar, to shore up the impermeability of the wall. But later, as Snelgrave, ever the class tourist, prods him for salacious stories of his life on the sea, Bunce pierces a ripe orange with Snelgrave's finger, bathing himself in the juice (48). The sticky sweet liquid becomes an inadvertent bond between the two men's bodies, a pleasurable, provocative, hungerinducing counterpoint to the antiseptic vinegar. While the vinegar wipes the trace of the body from the walls and floor in order to prove their authority as structural barriers, the orange juice sticks to hands, sticks hands together, becomes the forbidden mark of intercorporeal connection. The rind of the orange is both a metaphor for the layer of skin to be pierced in pleasure (sex) or pain (the lancing of plague sores), and that layer itself; it is an echo of Bunce's earlier burrowing into the house from beneath and a precedent for the pleasure his fingers will shortly take in Darcy's long-ignored body, and she in his. The orange is as large as the house and as tiny as illness's mark, as expansive as the body in pleasure and as contracted as the body in pain. It is the skin of Snelgrave's walls, not impervious after all; it is the skin of his wife Darcy's desire, lying vexed across the scarred surface of her longago burned and buckled flesh. Snelgrave assumes Darcy's body is closed and hard because scabbed and pocked, but the pockmarked orange proves this assumption a lie. Skin in this play is the terror of infection and the intoxication of embrace; skin is the moment of touch that might penetrate architecture's ocular fantasy of division, compartmentalization, control; skin is architecture's betrayal by the body, and the body's own architectural possibilities. ${ }^{18}$

As the play progresses, it undergoes a structural shift. The logic of the barrier governs Act 1, but by its penultimate scene a different structural logic - the shift from architecture as the wall 
and the locked door to architecture as the moment that risks embrace between bodies across difference-begins to take hold. This shift from the isolating to the intercorporeal is organized, arranged, and enabled by Morse's charged yet subtle theatrics. Morse breaches the house by stealth but locates her place within through performance: by pretending to be Lissa, she ensures protection from both Darcy and Snelgrave, even though Snelgrave finds her behaviour suspect $(13,17)$. Yet the charade will not hold: Snelgrave learns the truth by the end of Act 1 and, as the play readies to swap its skin, Morse swaps roles as well. Abandoning the charade of Lissa as Act 1 closes, Morse immediately expropriates from Snelgrave the role of director, which is to say the role of household head, arranger of household activities, and instigator of plot exposition. She takes over the play's dramatic trajectory: by 1.10 she has exposed Bunce and Darcy's illicit affection (34-35), her own performative roots (44), and in Act 2 she goes on to "perform" the Snelgraves with stick dolls in order to restage, childlike but deadly serious, their subjective and corporal relations. She wears Darcy's dress, inhabiting both child and mother, familiar and other, in a moment; she re-enacts Darcy's burning for Snelgrave, offering him the chance to remake the ending, to be more generous this time (56-57). Then, in a particular coup de théâtre, over the course of seven scenes (1.10 to 2.5) she rehearses, directs, and narrates Darcy's sexual re-awakening. Her metatheatrical machinations, progressing across the act-change from child-like mimicry to sophisticated performance, enable the play's houses/bodies/skins finally to reach their radical potential.

As Snelgrave prepares to expose her as a fraud in 1.10, Morse shifts the scene's attention to Darcy. She also shifts the epistemological superstructure of the scene, turning our attention from Snelgrave's taunting desire to see the belly scar that could prove Morse to be Lissa Braithwaite to Morse's desire to know how Darcy's burned skin feels (42). While Snelgrave rails, Morse lays her hands sensuously upon Darcy's arms, neck and breasts, feeling for the places where she remains sensitive to touch (42-43). The moment works in counterpoint to Snelgrave's demand that Morse expose her body as an object of show, as a thing to be judged from a distance rather than a being to be "caresse [d]" (43) at intimate quarters. As Snelgrave enacts the divisions between bodies enforced by the structural hierarchies of the house and the social hierarchies of the city beyond, Morse models an intercorporeal intimacy with Darcy that sets a precedent for Darcy's later sexual encounters with Bunce.

Margrit Shildrick and Janet Price argue, via Maurice Merleau- 
Ponty, that the body-in-contact is always both passive and active, always both touching and touched. The dynamic instantiated by touch is ambiguous, because reversible: "the world of each opens on the other" as touch crosses boundaries and frustrates imagined hierarchies. Humans crave tactility and yet are frightened of it exactly for this reason: to touch is to take a risk, to refuse, however momentarily, the logic of separation. As Shildrick writes in Embodying the Monster, touch is "the very thing that signals potential danger in a specular economy that privileges separation" (103); touch is the thing, in other words, that really risks bringing the house down. We might remember that classical architecture's economies are predicated on a sensory hierarchy crowned by the visual: the smooth white wall is a transparency through which we see normative social and sexual relations organized through and played out in plastic space, at a deliberate distance from the tactile and sensory reality of our bodies. Snelgrave's house is predicated on the same sensory hierarchy. If he can see Morse's fraudulence marked on her skin, he can justify erecting fresh boundaries between them. Had it not been a plague year, he could have thrown her out of the house and locked the door behind her. As it is, his impulse to banish her is frustrated not only by his inability to control his own thresholds, but also by Morse's insistence on elevating the status of tactile knowledge and physical intimacy within the space they of necessity share. As she champions the tender opacity of Darcy's damaged body over the supposed transparency of her own, she rocks his foundations.

Morse's caresses in 1.10 become a critical rehearsal for Darcy and Bunce's sexual encounters in Act 2. Mimicking almost exactly the gentle, exploratory pattern Morse employed earlier (54), Bunce finds his way slowly up Darcy's legs to her still-responsive vagina (54-56). In spite of its seeming utopic potential, however, this intimate moment cannot erase the class and gender differences that mediate it. Bunce remains the press-ganged sailor and sometime servant who narrates his hardship even as he brings his mistress to orgasm; Darcy remains the upper-class woman, mindful of the limits placed on her self-expression, who can barely speak her pleasure (56). It is not enough for the scene to articulate the tricky power dynamic between Darcy and Bunce (she as mistress, he as man; he as servant, she as woman), to leave it suspended in the moment of encounter. For such an encounter truly to become what Shildrick aptly calls a "chiasmatic relation," not "a merging in which all sense of self is forfeit, but rather a space of holding together in which radical difference replaces pale reflection" (Embodying 119, 
my emphasis), that power dynamic must become one of the sources of Bunce and Darcy's connection, a subject of their mutual remaking.

By Act 2, scene 5, Morse is fully in charge of the play's ground plan, and she choreographs the climactic scene of that remaking. The lovers' earlier encounter becomes known in the house; Snelgrave expresses his contempt for the relationship by taunting Bunce with a demand to know whether Darcy has "pleased" him (61). Darcy confesses she does not know how to do that. For Snelgrave, this confession becomes another excuse to abject Darcy, but Morse asks earnestly why Darcy may not learn to give her lover pleasure (62). She then explicitly inhabits her stealth role of director for the first time in the play: she tells Darcy and Bunce exactly where to stand; she instructs Darcy on what she must do. She moves and controls the scene like a seasoned pro, and her direction allows Darcy to find and articulate the sexual power her strict gender coding has long repressed and her burned body has long obscured. Over the surprise and protest of the males, Morse tells Darcy to lay her hands on Bunce's chest, give him a kiss, remove her glove, and reach down toward his belt; she then tells Darcy that "it's only polite" to ask permission of Bunce before continuing (63). This small instruction cracks the scene's chiasmatic potential wide open. Rather than reinscribing the power hierarchies operative in Bunce and Darcy's previous sexual encounter, Darcy's asking disturbs the oppressive dynamics of both master-servant and masculine-feminine lying between them. It momentarily refigures the violence implicit in sexual taking, in the social and sexual hierarchies of seventeenth-century England (and, for that matter, twenty-first-century North America). Touching replaces taking, asking replaces demanding, discovering replaces knowing. Differences between become the conduit to a momentary, pleasurable, and absolutely necessary intimacy. Darcy's battered skin and Bunce's pressed, bruised, and battered body renovate Snelgrave's divisional space with their own connective tissue as the certainties and prejudices of the eye give way to the pleasure and generosity of touch.

Performance is architecture's abject. Art made of bodiesmessy, interconnected, experimenting-performance reminds architecture of everything it embeds and forgets in the drive to produce the clean, white surface, the smooth and sexy glass wall, the line between you and me, the vista on the world that empowers the eye and leaves the flesh behind. Figures of radical performance like Nanabush, Beatrice Joanna, and Morse remind us not only of 
the power of the theatre to push us toward new and more equitable relations between bodies and subjects, but also of the power of those relations to unmake the strict divisional paradigms that structure our experience of the world as both metaphorical and literal space-as space built in both theory and practice. Architecture dreams a clean dream, but embeds the power of the messy, miraculous, intersubjective body; performance, as the unabashed art of that body, embeds the radical power of a rebellious, remembering architecture. To think performance and architecture theory and practice one through the other is to harness the power of the labouring, sexual, desiring body in "chiasmatic" connection with another labouring, sexual, desiring body as a model for reshaping the physical, psychic, and political dimensions of our world.

\section{Notes}

1 An earlier version of this paper was presented at the 2005 conference held by the Association for Canadian Theatre Research. It was awarded the Robert G. Lawrence Emerging Scholar Prize.

2 Morse revisits the story of Lissa Braithwaite's death at length in 2.6 of Naomi Wallace's One Flea Spare, to which I will return in detail later. She explains how she responded to Lissa's pleas for comfort-echoes of her mother's own-with a demand for Lissa's dress, shoes, the outward trappings of her status and identity; Lissa's bird, however, she finds herself unable to take. She lets the bird sing until its own heart stops and then places it in Lissa's mouth (64). This episode reminds me both of the old superstition that "a bird in the house means a death in the house" (immortalized by Margaret Laurence in her short story collection A Bird in the House), as well as of old spells and protective charms, the ancient ritual of placing beloved or meaningful objects in the mouths, hands, or caskets of the dead. Morse is both a consummate performer and a ritual-maker in this scene, and her work throughout the play relies on a heady combination of acting, sleight of hand, and the "plastic" trickery that enables the seeming magic of performance.

3 Elin Diamond writes, "Performance is that messy, historicizing moment that interrupts the integrity of the written document" ("Modern Drama/Modernity's Drama" 4; emphasis in original). Bodies, as I will contend, are those messy, historicizing figures that interrupt architecture's fantasy of a clean, smooth surface predicated on the perfect Apollonian shape, and that signify a moment of convergence between architecture and performance practices.

4 Like all disciplines, architecture has a number of origin stories. The one I rely on here is the standard version, the one that defines the classical building practices against which modern and post-modern 
architectures continue to react. Later, I'll hint at another, far more provocative, origin story. For a preview, see Bergren, "Architecture Gender Philosophy" and "Female Fetish Urban Form."

5 See Catherine Ingraham, "The Outline of the (Dead) Body" in Architecture and the Burdens of Linearity. Ingraham here speaks to the roots of architecture's corporeal anxieties, locating them in a sanitized geometry tradition. She tells the story of Pythagoras, notable for his school's "strict principles of sexual and bodily conduct. [A]fter getting out of bed, one was to always smooth out the imprint of one's body" (102). Ingraham argues that "it is precisely the rumpled imprint left by the sexually active body on the rectilinear plane of the bed" (102) that classical architecture, like classical geometry, fears and loathes. Alberti's wild fig is just such a fecund, sexual body: it risks the integrity of line, wall, structure.

6 Ingraham's Architecture and the Burdens of Linearity is a signal text for critics seeking to reframe core debates about the line and the wall in architecture theory and practice. Ingraham contends that the illusion of spatial relations as necessarily linear, perpetuated by classical as well as modernist building practice (she treats Le Corbusier at length), has established architecture as a discipline obsessed with propriety, property, and the proper name (the name of the father). The result has been a refusal to contend with the radical possibilities of non-Euclidean geometry and the alternative spatial relations for which it makes room, including those informed by alternative gender and sexual practices.

7 I echo Julia Kristeva's influential definition of "the abject" as that which menaces the subject from within and reminds me of the desiring body (bodies) I suppress.

8 I am riffing on Lacan's infamous argument about the split between the eye and the gaze; see "Of the Gaze as Objet Petit a" (Lacan 65119).

9 Two specific essays influence my thinking in this paragraph: "Brechtian Theory/Feminist Theory" and "Realism's Hysteria," both in Unmaking Mimesis.

10 "In historicized performance gaps are not to be filled in, seams and contradictions show in all their roughness, and therein lies one aspect of spectatorial pleasure-when our differences from the past and within the present are palpable, graspable, possibly applicable" (Unmaking Mimesis 50, emphasis in original).

11 We tend to think of performance space as a space of constant transformation, but, as Wolska points out, when we assume (along with, say, Derrida or Blau) that performance always brings a frisson of death with its end, we in fact freeze it into a stultifying temporal structure, rather than freeing it into the possibility of afterlife (86).

12 This charge against classical and modernist architecture theory has become infamous. In addition to Bloomer, Ingraham, and Wigley, see Bergren, and Grosz. 
13 I would like to thank TRIC's anonymous readers for helping me to clarify my position on this issue. I respond here to a specific anxiety over the legitimacy of the "dramatic text" that continues to haunt our work as scholars of theatre and performance; a quick glance at the mastheads of several key journals in our field (including, perhaps most famously, $T D R$ ) reveals how this anxiety manifests itself in practice, every day, in our collective scholarly production. While I am an enthusiastic performance analyst myself and am fully in agreement with the importance of continuing to advocate for the cultural significance of the performance event in the public sphere, I also believe that our disciplinary bias against text may embed certain risks we have not fully considered. For one thing, performance analysis implies access to the event itself, which implies a certain unspoken privilege. Who is privileged to view, often multiple times, certain performance events in order to be able to write with confidence about them? Who has access to the economic resources required to enable the kind of painstaking archival work the reconstruction of a past performance demands? When we debase the text, more easily accessed, in favour of the "ephemeral" event that is often by definition accessible only to a select few, what doors are we opening, and what doors closing, to future scholars in our discipline? Furthermore, as Shannon Jackson noted in her "State of the Profession" keynote at the 2005 ASTR conference in Toronto, when we debase the text, what might we be forgetting about the revolutionary place "text" and "writing" have come to occupy in other disciplines-such as architecture, for example? For more on the place of the text in theatre and performance studies today, see Jackson, Professing Performance, as well as Puchner.

14 See my "Violent Imaginings," especially 74-5. Note that the details I gleaned from exploring the original set designs are those largely included in the published text of Highway's play.

15 Mark Wigley does a thorough reading of the gendering of early modern domestic architecture, including a compelling exploration of the often slippery uses of the term "closet," in "Untitled: The Housing of Gender." Wigley notes the closet's self-fashioning function but, reading through Alberti's influential fifteenth-century writings on architecture, also points to the role of "closets" as sewers designed to contain human and animal detritus at an appropriate remove from the dwelling. The closet thus becomes a "spatial representation of pure order" (344) precisely as a result of its disavowed abjecting function: the private modern subject emerges through the shit the closet hides. On the early modern closet as a site of subjectformation see also Orlin 186-88.

16 This insight echoes Elin Diamond's discovery (in "Mimesis, Mimicry, and the (True Real") of a feminist theatre within Plato's cave as reconfigured by Luce Irigaray in Speculum of the Other Woman. 
17 The revenge enacted upon Beatrice Joanna in the final scene of The Changeling poses some problems for my reading of Beatrice Joanna's guerrilla performance in Act 4. Space constraints prevent me here from dealing thoroughly with the play's last moments, but I would briefly contend this: given that Beatrice Joanna is punished "within" the closet (that is, technically offstage), and given that we experience her punishment only through her ambiguous cries of "O!" as they resonate in the auditorium, the closet in fact never loses its performing function, the theatrical status Beatrice Joanna claims for it in Act 4. If anything, the closet's opaque theatricality remains a troubling marker of Beatrice Joanna's bodily and subjective dynamism throughout the final act. Certainly she suffers: all Jacobean bad girls do. But how she suffers is here up for grabs, and I would argue she suffers as an actor, not simply as a broken subject. See also Garber.

$18 \mathrm{I}$ am indebted in my thinking about this and other signal moments in One Flea Spare to Shannon Baley, whose consideration of the play through the lens of Jill Dolan's utopian performative has been influential for me. Of the orange episode, Baley writes, "Bunce's gestus of piercing the orange on the wealthy older man's finger is, on one level, defiant and brutal, gesturing to the systems of oppression just outside the action of the scene [...]. On another level, this gestus is highly seductive, Bunce using the orange as an erotic tool to show-rather than tell-his 'master' what a sailor 'does' to quench his desire on the high seas" (242).

\section{WORKs Cited}

Alberti, Leon Battista. On the Art of Building in Ten Books. Trans. Joseph Rykwert, Neil Leach, and Robert Tavernor. Cambridge, MA: MIT P, 1988.

Bachelard, Gaston. The Poetics of Space. Trans. Maria Jolas. Boston: Beacon, 1969.

Baley, Shannon. "Death and Desire, Apocalypse and Utopia: Feminist Gestus and the Utopian Performative in the Plays of Naomi Wallace." Modern Drama 47.2 (2004): 237-49.

Bergren, Ann. "Architecture Gender Philosophy." Whiteman, Kipnis, and Burdett 8-46.

— ."Female Fetish Urban Form." The Sex of Architecture. Ed. Diana Agrest et al. New York: N.H. Abrams, 1996.77-96.

Bloomer, Jennifer. "A lay a stone a patch a post a pen the ruddyrun: Minor Architectural Possibilities." Whiteman, Kipnis, and Burdett 48-66.

- Architecture and the Text: The (S)crypts of Joyce and Piranesi. New Haven: Yale UP, 1993.

— ."Nature Morte." The Architect: Reconstructing Her Practice. Ed. Francesca Hughes. Cambridge: MIT P, 1995. 236-50.

Diamond, Elin. "Mimesis, Mimicry, and the 'True Real." Modern Drama 32.1 (1989): 58-72. 
—. "Modern Drama/Modernity's Drama." Modern Drama: Defining the Field. Ed. Ric Knowles, Joanne Tompkins, and W.B. Worthen. Toronto: UTP, 2003.3-14.

—. Unmaking Mimesis: Essays on Feminism and Theatre. London: Routledge, 1997.

Garber, Marjorie. "The Insincerity of Women." Subject and Object in Renaissance Culture. Ed. Margreta de Grazia, Maureen Quilligan, and Peter Stallybrass. Cambridge: Cambridge UP, 1996.349-68.

Grosz, Elizabeth. Architecture from the Outside. Cambridge, MA: MIT P, 2001.

Highway, Tomson. Dry Lips Oughta Move to Kapuskasing. Calgary: Fifth House, 1989.

Ingraham, Catherine. Architecture and the Burdens of Linearity. New Haven: Yale UP, 1998.

Irigaray, Luce. i love to you: Sketch for a Felicity Within History. Trans. Alison Martin. New York: Routledge, 1996.

Jackson, Shannon. Professing Performance: Theatre in the Academy from Philology to Performativity. New York: Cambridge UP, 2004.

Kristeva, Julia. Powers of Horror: An Essay on Abjection. Trans. Leon S. Roudiez. New York: Columbia UP, 1982.

Lacan, Jacques. The Four Fundamental Concepts of Psychoanalysis: The Seminar of Jacques Lacan Book XI. Ed. Jacques-Alain Miller. Trans. Alan Sheridan. New York: Norton, 1981.

McEwen, Indira Kagis. Vitruvius: Writing the Body of Architecture. Cambridge, MA: MIT P, 2003.

Middleton, Thomas, and William Rowley. The Changeling. Ed. Joost Daalder. $2^{\text {nd }}$ ed. London: A \& C Black, 1990.

Orlin, Lena Cowen. Private Matters and Public Culture in PostReformation England. Ithaca: Cornell UP, 1994.

Puchner, Martin. “Entanglements: The Histories of TDR.” TDR 50.1 (2006): 13-27.

Shildrick, Margrit. Embodying the Monster: Encounters With the Vulnerable Self. London: Sage, 2002.

— , with Janet Price. “Thinking Through the Intercorporeal.” Lecture. University College, University of Toronto. 20 April 2004.

Solga, Kimberley. "Violent Imaginings: Feminist Performance Spaces in Tomson Highway's Dry Lips Oughta Move to Kapuskasing." Space and the Postmodern Stage. Ed. Irene Eynat-Confino and Eva Sormova. Prague: Prague Theatre Institute, 2000.71-81.

Stallybrass, Peter. "Patriarchal Territories: The Body Enclosed." Rewriting the Renaissance: The Discourses of Sexual Difference in Early Modern Europe. Ed. Margaret W. Ferguson, Maureen Quilligan, and Nancy J. Vickers. Chicago: U of Chicago P, 1986. 123-42.

Vitruvius (Marcus Pollio). The Ten Books on Architecture. Trans. Morris Hicky Morgan. New York: Dover, 1960.

Wallace, Naomi. One Flea Spare. In the Heart of America and Other Plays. New York: TCG, 2001.1-75. 
Whiteman, John, Jeffrey Kipnis, and Richard Burdett, eds. Strategies in Architectural Thinking. Cambridge, MA: MIT P, 1992.

Wigley, Mark. "Untitled: The Housing of Gender." Sexuality and Space. Ed. Beatriz Colomina. New York: Princeton Architectural P, 1992. 326-89.

Wolska, Aleksandra. "Rabbits, Machines, and the Ontology of Performance." Theatre Journal 57.1 (Mar 2005): 83-95. 